NBER WORKING PAPER SERIES

\title{
DID THE STIMULUS STIMULATE? REAL TIME ESTIMATES OF THE EFFECTS OF THE AMERICAN RECOVERY AND REINVESTMENT ACT
}

\author{
James Feyrer \\ Bruce Sacerdote \\ Working Paper 16759 \\ http://www.nber.org/papers/w16759
NATIONAL BUREAU OF ECONOMIC RESEARCH
1050 Massachusetts Avenue
Cambridge, MA 02138
February 2011

We thank Samuel Farnham for expert research assistance and the Institute for Education Science for generous funding. Doug Staiger and David Weil provided very helpful comments. The views expressed herein are those of the authors and do not necessarily reflect the views of the National Bureau of Economic Research.

NBER working papers are circulated for discussion and comment purposes. They have not been peerreviewed or been subject to the review by the NBER Board of Directors that accompanies official NBER publications.

(C) 2011 by James Feyrer and Bruce Sacerdote. All rights reserved. Short sections of text, not to exceed two paragraphs, may be quoted without explicit permission provided that full credit, including (C notice, is given to the source. 
Did the Stimulus Stimulate? Real Time Estimates of the Effects of the American Recovery and Reinvestment Act

James Feyrer and Bruce Sacerdote

NBER Working Paper No. 16759

February 2011

JEL No. E6,E62,E65

\begin{abstract}
We use state and county level variation to examine the impact of the American Recovery and Reinvestment Act on employment. A cross state analysis suggests that one additional job was created by each $\$ 170,000$ in stimulus spending. Time series analysis at the state level suggests a smaller response with a per job cost of about $\$ 400,000$. These results imply Keynesian multipliers between 0.5 and 1.0, somewhat lower than those assumed by the administration. However, the overall results mask considerable variation for different types of spending. Grants to states for education do not appear to have created any additional jobs. Support programs for low income households and infrastructure spending are found to be highly expansionary. Estimates excluding education spending suggest fiscal policy multipliers of about 2.0 with per job cost of under $\$ 100,000$.
\end{abstract}

\author{
James Feyrer \\ Department of Economics \\ Dartmouth College \\ 6106 Rockefeller Hall \\ Hanover, NH 03755-3514 \\ and NBER \\ james.feyrer@dartmouth.edu \\ Bruce Sacerdote \\ 6106 Rockefeller Hall \\ Department of Economics \\ Dartmouth College \\ Hanover, NH 03755-3514 \\ and NBER \\ Bruce.I.Sacerdote@dartmouth.edu
}




\section{Introduction}

On February 17, 2009, the U.S. Congress approved the the American Recovery and Reinvestment Act of 2009. Since then, the success or failure of the ARRA has been hotly debated. In arguing for the bill, supporters claimed that passage would increase output and decrease unemployment. The Chair of the Council of Economic Advisers, Christina Romer, presented the following graph to show the expected path of unemployment both with and without passage of the ARRA.

\section{Figure 1: Estimates of the Impact of ARRA at the Time of Passage versus Reality}

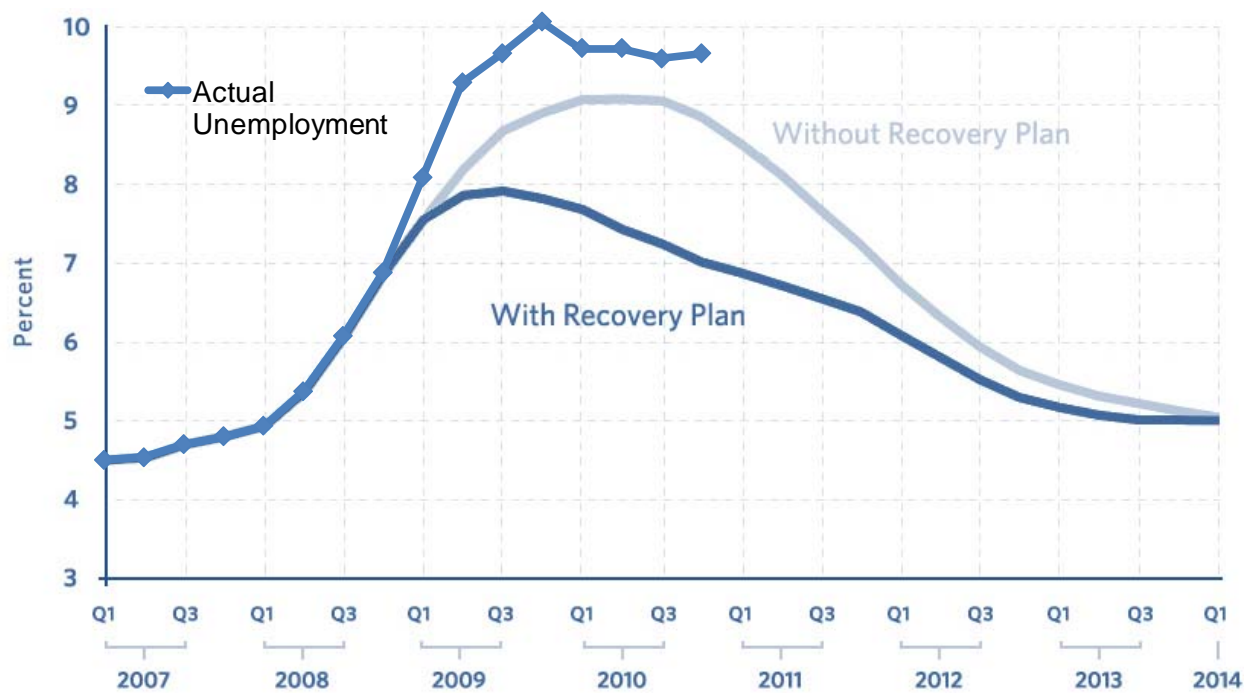

Added to the graph is a line showing the actual path of unemployment, which rose even faster than the scenario without the recovery plan. In fairness, it was impossible at the time to know exactly what the future path would be in either scenario. This graph was drawn starting with a baseline forecast without the ARRA and projecting the improvement that would occur if the ARRA were passed. It is possible that the stimulus was effective but that underlying conditions were much worse than predicted in January of 2009.

Unfortunately, direct evaluation of the impact of the bill has proven difficult. Most claims of success or failure have been based on the same models that were used to argue for or against the stimulus in the first place. To a first approximation, most evaluations of the stimulus take the difference between the simulated path of output from a scenario with and without the ARRA and substitute the actual path of unemployment for the scenario where the ARRA was implemented. The only new information that has been added is the actual timing of spending in the stimulus. 
Typical of this approach is Alan Blinder and Mark Zandi's "How the Great Recession Was Brought to an End." They use a modified version of a large macroeconomic forecasting model to plot the path of the economy both with and without ARRA. ${ }^{2}$ They conclude

...the effects of the fiscal stimulus alone appear very substantial, raising 2010 real GDP by about 3.4\%, holding the unemployment rate about $1 \frac{1}{2}$ percentage points lower, and adding almost 2.7 million jobs to U.S. payrolls

This conclusion, however, could have been written before the ARRA was implemented, knowing only the intended policy path. Their methodology does not take any account of the actual path of employment after the passage of the bill.

Many evaluations claiming failure of the ARRA suffer from similar problems. Other model based evaluations, such as Cogan, Cwik, Taylor, and Wieland (2009) conclude that the government spending multipliers are significantly smaller than those claimed by advocates. Again, their conclusions are based entirely from existing models and gain nothing from actual data on employment before and after the implementation of the ARRA.

In a post on the Congressional Budget Office's blog, CBO director Douglas Elmendorf is very forthright about the inability of these types of evaluations to evaluate actual results.

Although CBO has examined data on output and employment during the period since ARRA's enactment, those data are not as helpful in determining ARRA's economic effects as might be supposed because isolating the effects would require knowing what path the economy would have taken in the absence of the law. Because that path cannot be observed, the new data add only limited information about ARRA's impact. 3

The fundamental problem is the lack of a counterfactual. We do not know what the path of the economy would have been in the absence of the stimulus. Without a counterfactual, the best we can do is fall back on our models. Unsurprisingly, the models tell the same story today that they did when arguments for and against the stimulus were being made.

This paper aims to take a different approach to evaluating the efficacy of the ARRA by looking at state and local stimulus spending. We will use geographic and time series variation in stimulus spending to identify the effect of stimulus spending on employment. Did regions that received larger amounts of stimulus dollars have faster employment growth?

One potential difficulty with this approach is that regional variation in stimulus spending is not exogenous. Regions that have been harder hit by the recession may be receiving more transfers. In order to deal with this problem we turn to the political economy literature. Knight (2002)

${ }^{2}$ Specifically, Moody's Analytics model of the U.S. economy

3"Estimated Impact of the Stimulus Package on Employment and Economic Output”, CBO Director's Blog, Aug 24 2010, http://cboblog.cbo.gov/?p=1326. 
and others have found that the composition of congressional delegations has a significant impact on government spending. States with higher seniority in Congress tend to receive more money per capita than those with lower seniority. If we take congressional seniority to be unrelated to underlying economic conditions this should provide an instrument for spending at the regional level.

We will also examine the time path of the spending at the state level to examine the dynamic effect of stimulus spending. This approach more closely maps to the traditional fiscal policy literature by looking at the impulse response from a shock to spending. The advantage of this approach is that the exact time path of the payments from stimulus is likely to have a significant random component once the aggregate level of state spending is accounted for.

We will also disaggregate the spending by federal agency. In examining the spending patterns we found that the agencies fell naturally into three groups. The first group includes agencies providing block grants to fund local government employment. A large proportion of spending by the Departments of Education and Justice were used to fund teachers and police at the local level. The second group consists of support to low income families. Spending by the Departments of Agriculture, Health Education and Welfare, and Housing and Urban Development had a large component of support to low income individuals (food stamps, Medicaid, and rental assistance). The spending of the third group largely consisted of paying for new infrastructure projects. This group includes the Departments of Transportation and Energy which funded building projects. The results for each of the individual agencies within a group are very similar.

To preview the results, we find that the stimulus had modestly lower impacts than predicted by the administration, though their estimates are well within our confidence interval. The overall results mask significant heterogeneity by type of spending. Transfers to local governments and school districts to support teachers and police appear to have no positive effect on employment. Programs funding support for low income households generate the largest employment response. Building projects generate a smaller, but still substantial response. Excluding the transfers to local schools and governments, the cost of a job in the stimulus was less than $\$ 100,000$ per year. Including the transfers to local school districts, this cost increases by at least a factor of two. The implied Keynesian multipliers are between 0.5 and 1.0 in the aggregate and rise to 2.0 if one excludes education spending.

\section{Literature Review}

The impact of fiscal policy on output has been studied extensively. Empirical work in this field typically estimates Keynesian multipliers of the sort that underlie the Romer-Bernstein estimates of the impact of the ARRA. The size of these multipliers played a crucial role in evaluating the potential efficacy of the ARRA, with advocates arguing that multiplier are large and critic arguing that they are small. Unfortunately, unbiased estimates of fiscal multiplier effects are difficult to produce because fiscal policy is generally a response to economic conditions and therefore endogenous. 
There have generally been three approaches used to solve the identification problem created by the endogeneity of spending. First, is the use of structural vector auto-regressions (SVAR) pioneered by Blanchard and Perotti (2002). They find spending multipliers in the vicinity of one. More recently, Auerbach and Gorodnichenko (2010) find that fiscal policy is more effective during recessions, finding multipliers as high as two, though they find that this is mostly concentrated in military spending.

The second approach is to search for episodes of fiscal policy innovations that were not motivated by current economic conditions. The most recent work by Romer and Romer (2010) on tax changes in the US uses this approach. They examine the narrative record to find episodes where congress changed tax laws for reasons that excluded current conditions. Some of the exogenous changes they identify are those related to budget deficit reduction or that are ideologically driven. They find multiplier in the range of about three for exogenous tax changes in the US.

Other papers using this general approach use changes in military spending as exogenous shocks. These papers include Barro (2009), Ramey and Shapiro (1998), and Ramey (2008). These papers tend to find multipliers that are less than one. Feyrer and Shambaugh (2009) exploit the Romer and Romer shocks to look at the impact of US fiscal shocks on the rest of the world. Their results suggest a significant proportion of tax shocks are absorbed abroad.

There has also been some work done using state level variation in spending. Shoag (2010) uses variation in state pension plan returns to instrument for state spending and finds a multiplier of about two. \$35,000 in spending is associated with one additional job. Clemens and Miran (2010) exploit the variation in state level balanced budget rules to identify the effect of fiscal policy at the state level. They find that $\$ 25,000$ in additional state spending results in one additional job. This suggests a rather large fiscal multiplier at the state level.

One potential problem with all previous work in fiscal policy is external validity. The size of the ARRA is much larger than anything we have seen before, the output gap is much larger, and the Federal Reserve is at the zero bound. All three factors suggest that the response of the economy to the ARRA is likely to be different than the response to increased military spending and tax innovations that occurred during periods of small output gaps. The response of the economy to fiscal policy is also dependent on the Federal Reserve's response function. Woodford (2011) suggests that the multipliers will be higher when interest rates are at the lower bound.

There is also reason to believe that the type of spending matters significantly. Standard Keynesian theory suggests that direct government spending will have a larger impact than transfers. The impact of transfer payments will be higher for high marginal propensity to consume individuals. This makes it difficult to draw conclusions about the ARRA based on studies that are limited to military spending or tax changes taking place under non-recessionary conditions.

The fact that multipliers may vary greatly by type of spending, amount of spending and economic conditions suggests that a direct examination of the current episode may be useful. As 
discussed in the introduction, very little discussion of the ARRA has incorporated real time data. There are two notable exceptions to this. Wilson (2010) has written a state level analysis of jobs and stimulus spending that we draw on for our state level results. He finds that the ARRA had positive stimulus effects, but that the results are sensitive to the time frame over which the evaluation is taking place. We will go beyond his work by using county level variation and focusing on the time series variation in spending. Cogan and Taylor (2010) have looked at the impact of grants to the states in the ARRA and conclude that states did not alter spending significantly as a result of the stimulus.

\section{Methodology}

The fiscal policy literature generally expresses impacts in terms of fiscal multipliers. That is, how much additional GDP will be produced for each dollar of additional government spending? Like Wilson (2010), we will focus on change in the number of jobs rather than the level of output. The main reason for this is data constraints. We have good monthly measures of the number of people employed at the state level. We do not have similar real time numbers for state GDP. Employment and GDP are, of course, closely related and we will do some simple transformations using the Okun's law relationship between employment change and GDP growth.

The analysis that we present is necessarily preliminary. It has only been 20 months since the first dollars started to arrive and fiscal policy is generally thought to take 24-36 months to reach full impact. We take three general approaches. First, we examine the overall change in employment over the sample period against the overall quantity of stimulus spending at the state level. This is quite similar to work done by Wilson (2010) at the state level. Second, we do the same exercise at the county level. Finally, we examine month by month spending at the state level and generate impulse responses of employment to the state level spending changes.

These three approaches have very different sources of identification. The state level cross section gives the broadest picture with the most complete data. Because the identification is coming from state level variation, we can control for aggregate national shocks. The county level analysis allows us to further control for state level shocks, exploiting the idiosyncratic differences in spending by county. The time series results similarly allow us to control for the aggregate level of state spending and get identification though the idiosyncratic timing of the spending.

After examining the effects of overall stimulus spending on employment we further cut the data to look at different types of stimulus spending (do block grants for teachers have a different impact than expanding food stamp eligibility?) and different types of employment responses (did the stimulus create more education jobs than construction jobs?)

One disadvantage of moving to disaggregated data is that we miss any nationwide and global impacts from ARRA. The multiplier effects from stimulus spending at the local level will be reduced by the marginal propensity to import from outside the region being examined. This will potentially be more important for some kinds of spending than others. Road construction is a 
localized phenomenon in some regards (wages will be paid in the state where the road is built), but national in others (new equipment and materials may be sourced out of state). Low income individuals may be more likely to spend locally than middle income individuals. This effect will also necessarily reduce the county level impacts relative to the state level.

For this reason the positive effects on job growth and wages that we find will likely be lower bounds and possibly significant understatements of the total effects of ARRA. One goal of ARRA was to increase business and consumer confidence nationally. We do not capture these aggregate effects.

\section{IIIa Cross Sectional Analysis}

We regress the change in employment per capita on stimulus spending per capita at the state and county level,

$$
\begin{aligned}
& \text { sepop }_{i}=\alpha+\beta * \text { Stimulus per capita } i+\epsilon_{i} \\
& \Delta \text { epop }_{i}=\alpha+\gamma_{\text {state }}+\beta * \text { Stimulus per capita } i+\epsilon_{i}
\end{aligned}
$$

where epop is the employment to population ratio. The county level regressions allow for the inclusion of state level controls.

Since we are regressing jobs per capita on stimulus per capita, our coefficients can be interpreted as jobs per hundred thousand dollars. This is a loose interpretation since in reality there is a flow of spending creating a flow of jobs. Since the time series results explicitly deals with the time path, this is less of an issue for these results.

One concern with our cross sectional approach is that stimulus spending is likely to be endogenous. States that were hardest hit by the recession may have received disproportionate amounts of stimulus spending. At the state and county level we deal with this concern by turning to the political science literature on the relationship between relatively idiosyncratic political power and spending. States with longer serving congressional delegations have higher seniority and more access to committee chairmanships and other leadership positions.

Higher seniority at the state level is therefore positively correlated with federal spending by state. We will exploit this variation to instrument for the level of stimulus spending. For each House and Senate member we collected current party, years of seniority, seniority rank relative to other House (Senate) members, and Chair of any committees or Caucus. We have tried predicting stimulus spending per capita using mean ranks (seniority with 1 being the most senior) of a state's House and Senate delegations and with the number of committee chairs held by the House and Senate delegations.

Empirically ARRA spending per capita across states is not particularly correlated with committee chairs or with the seniority of a state's senators. However, the mean seniority of a state's House delegation is strongly correlated with the stimulus dollars per capita received by a state. Our finding in this regard is consistent with the existing political economy literature 
which also uses mean seniority at the state level to predict spending. As a result we confine ourselves to using mean seniority of the House delegation as our single instrument for stimulus spending per capita.

Another predictor of stimulus per capita is the population of the State. Small states such as Montana and Wyoming received many more dollars per capita than more populous states. This could be a result of the structure of the Senate (ie two Senators per state regardless of population) or it could be in part a reflection of the fact that less populous states have many more miles of highways and bridges per capita than densely populated states. However we are naturally concerned that population size may be directly correlated with employment and wage growth during the recession and we therefore we report robustness checks that include the log of population as a control on the right hand side rather than using as it an instrument.

\section{IIIb. Dynamic Responses}

We also look at the impact of the stimulus spending in a state level panel. By using a monthly panel we can control for the overall level of stimulus spending at the state level, getting identifying variation from the changes in spending on a month to month basis. For these regressions we do not have the luxury of an instrument for spending. However the time series allows us estimate the impacts in differences, effectively controlling for state level difference in the size of the initial shock. Our identification is coming from idiosyncratic differences in the timing of spending at the state level.

There are clearly some types of spending for which relying on the timing of spending is more problematic than others. In particular, spending on unemployment insurance is directly tied to the level of unemployment. For this reason we will exclude unemployment insurance in some specifications. It should be noted that the bias from programs tied to economic performance is against finding an effect of the stimulus.

The analysis follows the approach of Romer and Romer's paper examining tax changes. We regress the change in the employment to population ration on a set of leads and lags of the change in spending. By summing these coefficients we generate the response over time to a permanent change in spending. The basic regression is:

$$
\Delta \text { epop }_{i t}=\gamma_{t}+\sum_{j=- \text { leads }}^{\text {lags }} \beta_{j} * \Delta\left(\text { stimulus per } \text { capita }_{i, t-j}\right)
$$

The summation of the lag coefficients,

$$
\text { response }_{t}=\sum_{j=0}^{\text {lags }} \beta_{j}
$$

gives the response to a permanent change in spending per capita at various time horizons. These responses functions will be presented as graphs. All results use 2 leads and 8 lags, though the results are not sensitive to different lead and lag structures. Compared to the traditional 
fiscal policy literature we are looking at relatively few lags. This is necessitated by data constraints.

\section{Data}

Data on stimulus spending comes from the website www.recovery.gov which is maintained by the US federal government. 4 We use two different measures of stimulus spending. First, we use what are called "Agency Reported" data at the state level. These data are reported by roughly 25 major federal agencies and detail what dollars were allocated to which states. The agencies include all of the cabinet level departments such as Department of Transportation and Department of Education as well as the Social Security Administration, the National Endowment for the Arts, the National Science Foundation etc. We will use both the aggregate spending across all agencies and the individual agency spending for the larger agencies. For the panel data, we use monthly outlays to each state as reported as reported by each Agency. Table 1 lists agencies with over $\$ 100$ million in spending through September 2010 followed by categories that received over one billion dollars.

Means for the state level data are shown in the first panel of Table 2. Spending is reported in two different ways, obligations and outlays. Obligations represent projects that have been approved, but may not have received funding. Outlays represent money that has actually been disbursed to projects. For the cross sectional results, the choice of which to use is not particularly important as they track each other closely. For the time series results we use the outlays data on actual money spent. Our understanding is that projects present bills for reimbursement after work has been completed so that the timing of outlays closely matches the performance of the funded project. Obligations are a much less clean source of time variation.

Stimulus per capita averages around \$1100. The state level (Agency Reported) data on funds announced account for about $\$ 280$ billion worth of spending. We expect the total to be significantly less than the $\$ 765 \mathrm{~b}$ ARRA since $\$ 288 \mathrm{~b}$ of that total was allocated to tax relief and much of the spending beyond tax relief was allocated to entitlement programs including extensions of unemployment insurance.5 Of the total ARRA money, $\$ 452$ billion is part of agency spending that is captured in the agency reports as funds available. Only $\$ 347$ billion of the $\$ 452$ has actually been announced as part of specific grants, loans and contracts. Of the $\$ 347$ billion that has been announced, only $\$ 284$ billion is allocated to specific states with the other $\$ 63$ billion being federal spending not allocated by the agencies to a state.

The second source of data is "Recipient Level Reports." These are reports submitted by individual state governments, departments within state governments, local school districts and individual private contractors. These data include 362,000 reports of stimulus money received. These reports include everything from the $\$ 4.4$ billion block grant received by the State of California to support employment within public secondary and elementary education to the $\$ 1,806$ received by Bizzak Logging to treat noxious weeds on Forest Service land. ${ }^{6}$

\footnotetext{
${ }^{4}$ Specifically we pull data from this location: http://www.recovery.gov/FAQ/Pages/DownloadCenter.aspx

${ }^{5}$ See http://www.recovery.gov/About/Pages/The_Act.aspx. We are still surprised that the Agency reported data do not add up to a larger figure given that

${ }^{6}$ Details on which recipients are required to report can be found in this document:
} 
The recipient reports are necessarily less accurate and complete than the agency reports. They do, however, have two advantages. First, the recipient reports are at the county level where the agency reports are at the state level. We aggregate the recipient reports to the county level by using the 5 digit zip code of the ARRA recipient. ${ }^{2}$ Second, the recipient reports include data such as reported jobs created that are not available in the agency data. These are obviously imperfect, but it may be of interest how many jobs the recipients claim to have created or saved.

One problem is that we wish to avoid double counting that would occur by treating a large block grant received by a state as if the grant had all been spent at the state capital. To avoid double counting, we use the dollars reported as the "local amount" spent as opposed to the total grant. As an added precaution we also drop all money received directly by state agencies and state governments since the vast majority of those dollars are block grants which are subsequently sent to local governments and to contractors who themselves report the receipt of the money. Finally we drop the counties that contain the state capitals.

There is still no guarantee that all of a given grant or contract was spent within the confines of the county of the reporting receipient. Spending in a given county can clearly spill over to employment or wages in a neighboring county. As such we expect the measurement error of where the money is actually spent to cause our county level estimates of the impact of ARRA to be smaller than our state level estimates.

The means in Table 2 panel 2 show that stimulus per capita averages $\$ 304$ in the average county. This equates to roughly $\$ 85$ billion in spending that we can allocate at the county level. Prior to our attempt to allocate to the county level, the recipient level data have local spending amounts for about $\$ 237 \mathrm{~b}$ worth of spending. When we drop amounts that are associated with block grants which are sent to state agencies, we are left with $\$ 176$ billion. The fact that we are using "local amounts" as opposed to total award amounts should have already eliminated this block grant issue but it appears that some large state level grants remain classified as local spending. Furthermore of the $\$ 176$ billion, we can only allocate $\$ 85$ billion to counties. Most of the remaining amounts do not have zip codes in the data. ${ }^{8}$

Our data on employment and earnings come from the Bureau of Labor Statistics. 9 At the state level we pull monthly employment and earnings data from the Current Employment Statistics (CES) survey. To collect these data, state agencies assemble data for a large sample of establishments. Roughly 140,000 businesses and governments are sampled and this represents 410,000 individual worksites.

http://www.recovery.gov/About/Documents/InitialRecoveryActImplementingGuidance_Feb18.pdf.

${ }^{7}$ We associate each zip code with a county using a cross walk file developed by the University of Missouri Census Data Center. ${ }^{7}$ When zip codes cross county lines we assign the zip to the county containing the largest portion of the zip code population.

${ }^{8}$ We do have congressional district associated with these awards and we could in theory allocate to counties based on that but this is not likely to be terribly accurate.

${ }^{9}$ See http://www.bls.gov/data/\#employment 
For our state and state by month panel we consider the difference in employment per capita across two different months. For the cross sectional results we calculate the effect of ARRA based on the change in log employment between February 2009 and October 2010. Our baseline results are for total employment but we also consider the effect of ARRA on all government employment, federal, state, local government employment and private sector employment.

For county level employment and earnings we pull data from the Quarterly Census of Employment and Wages (QCEW). These data come from quarterly tax filings submitted to state agencies in connection with Unemployment Insurance. The program covers more than 99 percent of all wage and salary civilian workers. For earnings, we use average weekly earnings of all private sector employees. We regress the change in $\log$ (weekly earnings) on stimulus spending per capita.

Our data on the seniority of members of Congress comes from the list maintained by Wikipedia. ${ }^{10}$ We spot checked it and found it to be accurate.

\section{Results}

In Table 3 we present our baseline results at the state level. In column (1) we regress the change in employment per capita (from 2/09 to 10/10) on stimulus spending per capita in hundreds of thousands of dollars. We find a coefficient of 0.54 which suggests that each $\$ 100,000$ spent created 0.54 jobs. If we control for the log of population, the coefficient rises to 0.59 (column 2).

The basic state level cross sectional result can be seen in Figure 2 in which we show a scatter plot of changes in the employment to population ratio over the period against stimulus spending per capita. There is a clear positive relationship between employment outcomes and spending per capita. Alaska is a clear outlier having received more than $\$ 2,000$ per capita. If we drop Alaska, the slope changes from .54 to .67 .

We are concerned about the possible endogeneity of spending and in particular more money may have been sent to states that were hardest hit by the recession. To control for this selection we instrument for stimulus spending per capita using the mean seniority in a state's delegation to the House of Representatives. We measure seniority as the rank ( 1 to 435) with 435 being the least senior.

As expected, states with less senior delegations receive fewer stimulus dollars per capita. This first stage is shown in column (4). Mean seniority rank has a standard deviation of 50. A one standard deviation decrease in seniority (i.e. mean rank increases by 50) is associated with a decrease of $\$ 165$ per capita of spending. Economically this is meaningful and represents a 0.48 standard deviation drop in stimulus per capita.

\footnotetext{
10 See

http://en.wikipedia.org/wiki/List_of_current_members_of the_United_States_House_of_Representatives_by_senior ity
} 


\section{Figure 2: Long Change in Employment versus Stimulus Spending Per Capita}

spending per capita is in hundreds of thousands of dollars per capita. Change in employment is difference in employment per capita from Feb 2009 to October 2010

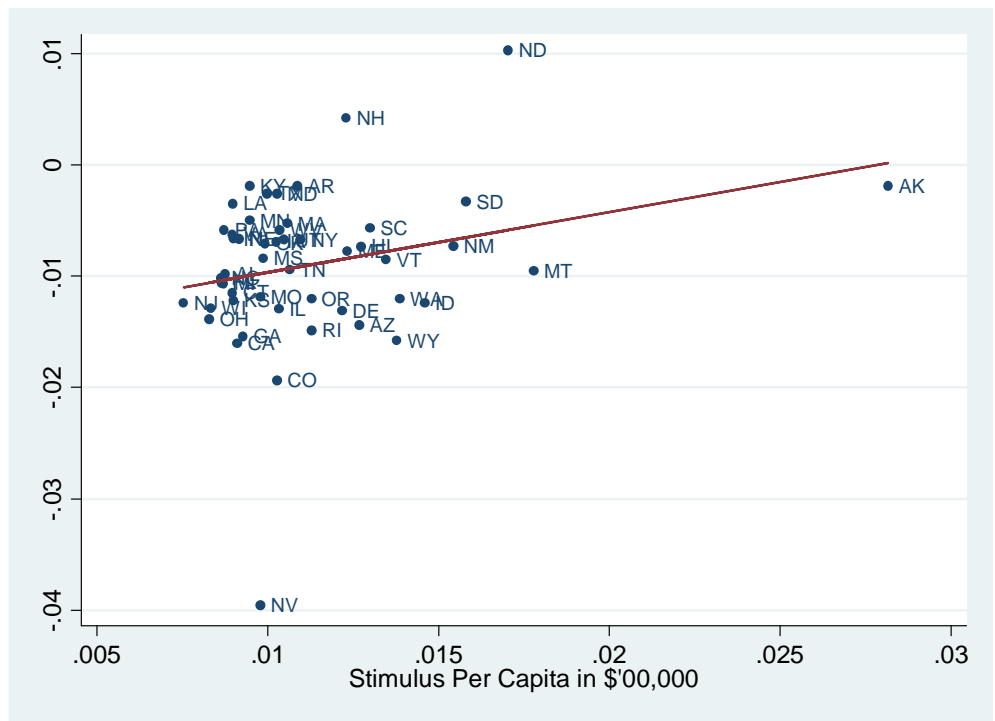

The second stage of the instrumental variables regression is shown in column (3). The result implies that a $\$ 100,000$ increase in stimulus creates one additional job. The t statistic on this coefficient is 1.79 .

To try to increase precision we try running a similar regression with a state*month panel. These results are shown in columns (5)-(6). Rather than using the difference in employment per capita as the dependent variable, we use the level of employment per capita and include state fixed effects. We cluster standard errors at the state level. An advantage of the state month panel is that all pre and post observations for employment are used rather than simply two endpoints. In the panel OLS (column 5), a $\$ 100,000$ increase in spending is associated with a 1.4 additional jobs. In the IV results (column 5 ) this coefficient rises to 2.3 jobs.

To put these numbers in perspective we attempt to translate them into dollars spent per job year and we compare our results to White House assumptions. The OLS coefficient in column (1) implies that $\$ 100,000$ created .54 jobs. Since this takes place over roughly 20 months (Feb 09 to August 10) we could think of this as $0.54^{*}(20 / 12)$ job years which implies roughly $\$ 111$,0oo per job year. If we take the larger OLS estimate from the state month panel, we get $\$ 43$,ooo per job year. The White house anticipated that during 2010, ARRA spending would create 3.0 million jobs from $\$ 787$ billion of spending. (See the Jobs Report issued in May 2009). ${ }^{11}$ If we assume that these three million jobs existed over the entire 20 month period, that would imply $\$ 157,000$ per job year.

\footnotetext{
${ }^{11}$ See http://www.recovery.gov/About/Documents/Jobs_Report_Final.pdf.
} 
In Table 4 we run the state month panel specification but we divide employment into government versus private employment. Column (1) shows that a $\$ 100,000$ increase in stimulus per capita is associated with a .20 government jobs. Columns (2)-(4) show that most of this effect (0.13) comes from local government jobs. The fact that very little of the effect comes from federal jobs is reassuring especially as we are excluding Washington DC from the analysis. The effect on private sector jobs is much larger with each $\$ 100,000$ creating .90 private jobs.

Table 5 breaks down the stimulus spending by federal agency that disbursed the funds. As mentioned above we group the agencies into ones that represent block grants to states to maintain employees, infrastructure (Departments of Energy and Transportation) and agencies that provide support for low income families and individuals (HHS, HUD and USDA). The point estimates are extremely noisy but may suggest that infrastructure spending and low income supports are more effective at creating jobs than block grants to states.

Table 6 is our county level analysis of effects on employment. The benefit of moving to the county level is the potential for more identifying variation. This comes with two large costs. First, as detailed above, we are only able to correctly apportion $\$ 85$ billion of the spending to counties. Second, the potential for spillovers across counties is quite large. The spillovers could result from macro multipliers as income earned from stimulus work is spent in other counties becoming income for another person. But the even simpler "spillover" story is that money labelled as being received in one county may be spent in a neighboring county as the private contractor or local agency carries out its mission.

Both because of measurement error and because of spillovers across counties, we anticipate that our county level coefficients will be smaller than our state level coefficients. This is what we find. The OLS results in column (1) imply that each $\$ 100,000$ of stimulus spending per capita results in 0.15 jobs. In column (2) we weight by county population and the coefficient falls to 0.04 jobs.

We again attempt to instrument for stimulus spending with the mean seniority rank of a state's House of Representatives delegation. Even though the first stage regression (Column (5)) works as before, the second stage suggest very large effects from spending on employment at the county level. Each 100,000 spent is associated with 3 additional jobs.

In Table 7 we turn to the effects on log (earnings) using the county level data. In the OLS, a $\$ 100,000$ increase in stimulus spending per capita is associated with a 275 percent increase in earnings. Putting this on a scale closer to the actual level spent, we could think of this as a 2.75 percent increase in income from each $\$ 1000$ in stimulus per capita. While seemingly large, these numbers are plausible given the massive size of the ARRA. Suppose we take US GDP per capita to be \$47,000 (CIA World Factbook) and that labor's share of GDP is 70 percent (St. Louis Fed 2004) ${ }^{12}$. And suppose ARRA spending on grants and contracts was $\$ 450 b$. These figures imply that ARRA spent $\$ 1607$ per American on grants and contracts relative to U.S.

\footnotetext{
${ }^{12}$ http://research.stlouisfed.org/publications/net/20040801/cover.pdf.
} 
labor income of $\$ 32,000$. That means that ARRA spending was a full 5 percentage points of total US labor income and this number falls between our OLS and our IV estimate.

Finally in Table 8 we switch the dependent variable to recipient reports of "jobs created or saved." These are the jobs reported in the recipient level reports and these are highly correlated with reports of money received. We use the county level data to regress reported jobs created or saved (expressed as a fraction of the county's baseline number employed) on reported dollars per capita spent. Each $\$ 100,000$ spent is associated with a 0.36 increase in jobs. Our scaling calculation suggests a cost per job year of $\$ 167,000$. Again this assumes that the job was created for all of the 20 months in the sample and then disappeared after the 20 months. More realistically the average job probably was not created immediately in February 2009 but could last significantly after October 2010.

\section{Time Series Results}

The time series results are presented as impulse response functions. (Tables 9 and 10 contain some of the underlying regressions). The sums of the coefficients presented in the impulse response graphs are the cumulative change in the employment to population ratio over time after a spending shock scaled to $\$ 100,000$ per capita. Because both the spending and jobs counts are scaled to population, the coefficients can be interpreted as the number of jobs per $\$ 100,000$ per month increase in spending. On a yearly basis it is the number of jobs for each $\$ 1.2$ million in spending. All response functions are surrounded by a band indicating the 90-10 percent confidence interval. Figure 3 shows the overall impact of the ARRA.

The overall response is modest, with an increase of 2-3 jobs per $\$ 100,000$ increase in monthly spending. It takes about 3 months for the full impact to take place, after which the impact is relatively constant. In terms of yearly spending the cost was about $\$ 500,000$ per job. The standard errors are large and we cannot reject that the impact is nearly twice as large. Typically fiscal policy shocks are found to take 3-4 quarters to have their full impact. Given the short time series that we have available, going beyond 3 quarters is impractical at this point. The effects appear to be leveling off at a lag of 8 months. Estimates done using a larger number of lags suggest the impacts are peaking at this point and potentially beginning to move downward.

Examining the impact by type of spending reveals interesting differences. Figure 4 shows the impact of spending at the agency level for agencies spending over one billion dollars by September, 2010. Grouping agencies with similar patterns reveals three major groups.

First are agencies that are engaged in grants for building projects. Department of Transportation ARRA money largely is being spent on highways, ports, and airport projects. Department of Energy and Environmental Protection Agency projects similarly are funding energy and environmental projects. In both cases, the money appears to be funding projects that were unlikely to take place in the absence of the funding. 
Figure 3: The Overall Impact of the ARRA

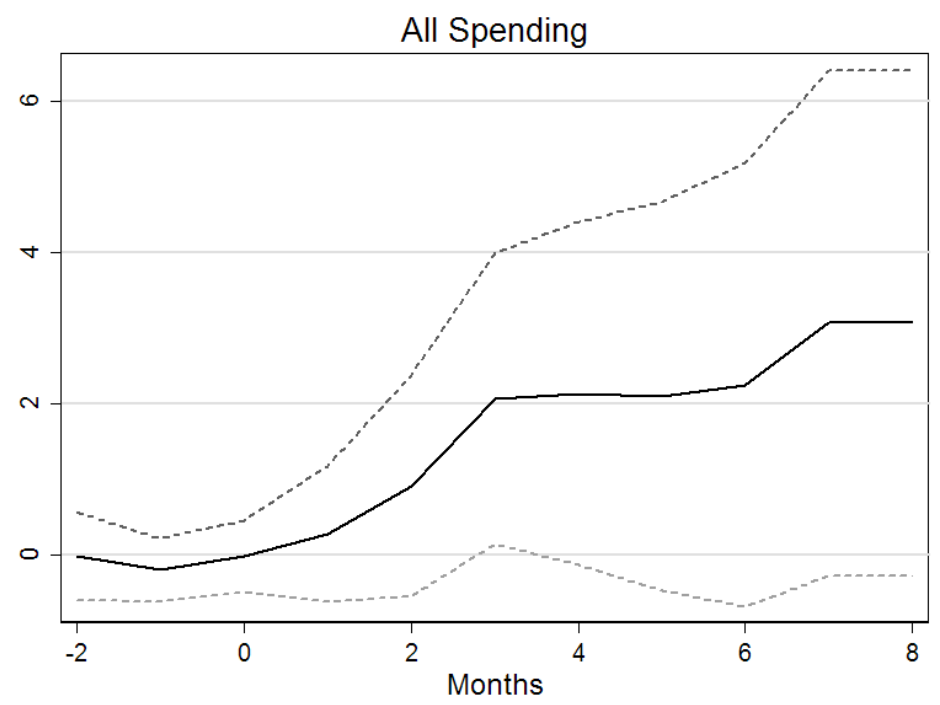

Figure 4: Agency level impacts of the ARRA (agencies over \$10 billion)
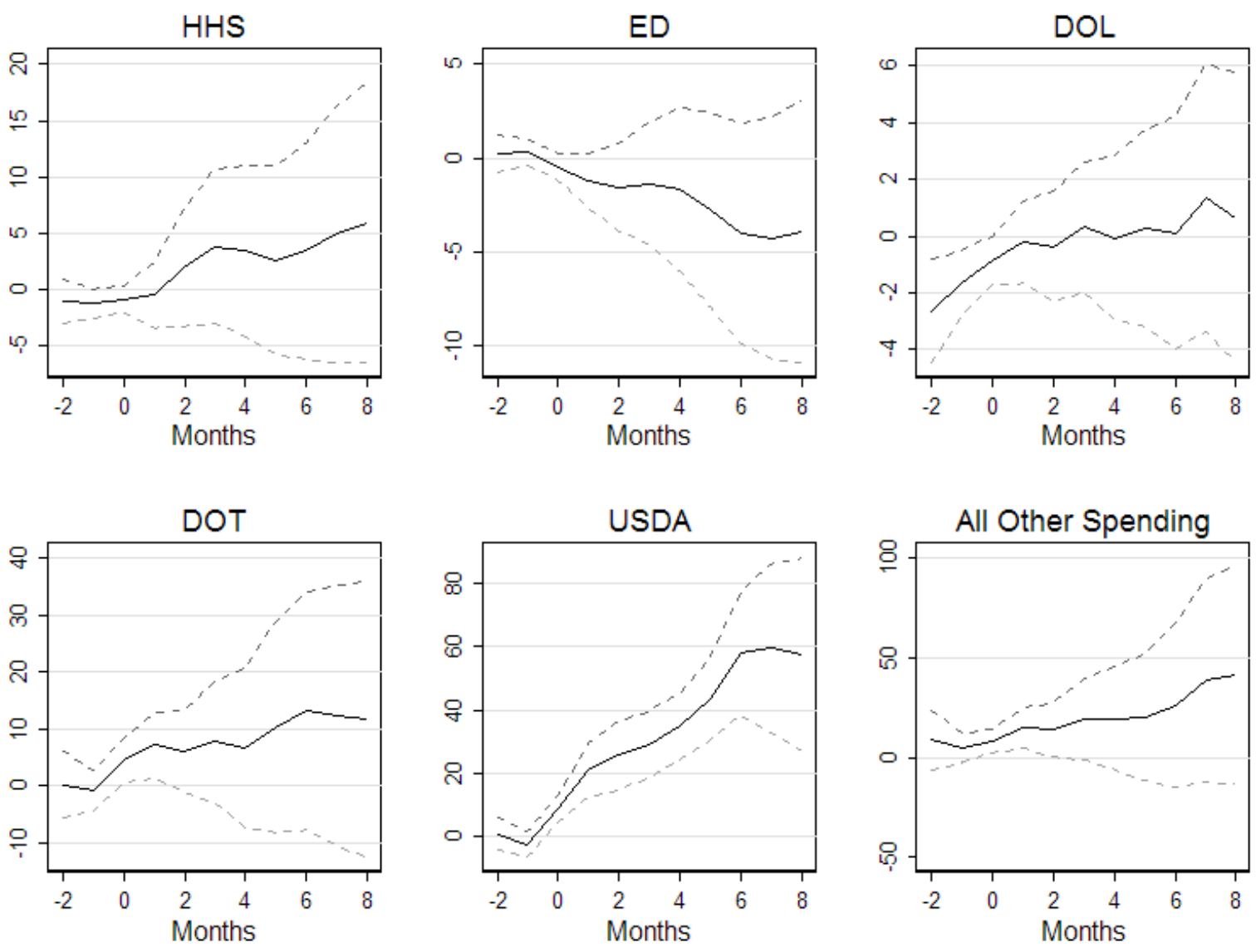
The second major grouping is support programs for low income households. The majority of USDA spending went to an expansion of food stamps. HUD spending was spent on rental assistance and public housing projects. HHS spending went to Medicaid. A substantial part of the money for low income support came in the form of matching funds to the states, particularly Medicaid. We therefore may worry that this money was essentially a fungible transfer to the states despite the nominal targeting of low income individuals. This concern is mitigated by the fact that the money was only available if states agreed to leave existing eligibility rules in place. In other words, states were obligated to cover the additional individuals that became eligible due to the recession and could not simply use the money to cover imbalances elsewhere. This money was also in the form of an increase in the rate of matching funds, so decreases in state level support reduce the level of federal transfers.

The third major grouping was in the form of grants to local governments to support teachers and police from the Departments of Education and Justice (Homeland Security also spent some money supporting first responders, but this was a relatively small amount). As far as we can tell, this money came with far fewer structural restrictions compared to the state level transfers for low income support. Municipalities had more flexibility to use this money to offset other budget categories.

The only major funding agency that does not fit neatly into these three categories is the Department of Labor, whose spending largely went to extensions of unemployment insurance. This spending is obviously problematic for our analysis because the distribution of these funds is directly related to the employment rate. Extension of unemployment insurance also benefits a much more diverse income group than the low income support programs (though clearly beneficiaries are experiencing a temporary shock). Interestingly, this is the only agency that shows a substantial pre trend in the effects of the stimulus.

Figure 5 shows the impulse response functions by each of these groupings. The differences become more obvious in this view. Support for low income households have the largest positive impact, followed by transportation and energy projects. Transfers to municipalities to fund teachers and police have if anything a negative impact.

Figures 6 and 7 zoom in on the components of the two larger spending categories. All three low income support programs have a positive impact, but the effect is larger for the two programs that directly give cash, food stamps and rental assistance. In both cases the impacts are significant at the 99 percent level. The transfers to municipalities are negative in all three cases, though not significantly so.

Figure 8 shows the results of including everything but education and unemployment extension spending in the analysis. Non education stimulus has a significant positive impact on employment and is significant at the five percent level three and four months after the shock (and at the ten percent level for most other time horizons). An increase in spending of $\$ 100,000$ dollars per month will generate a bit over 10 jobs. Assuming that these coefficients 
Figure 5: Responses by Types of Spending
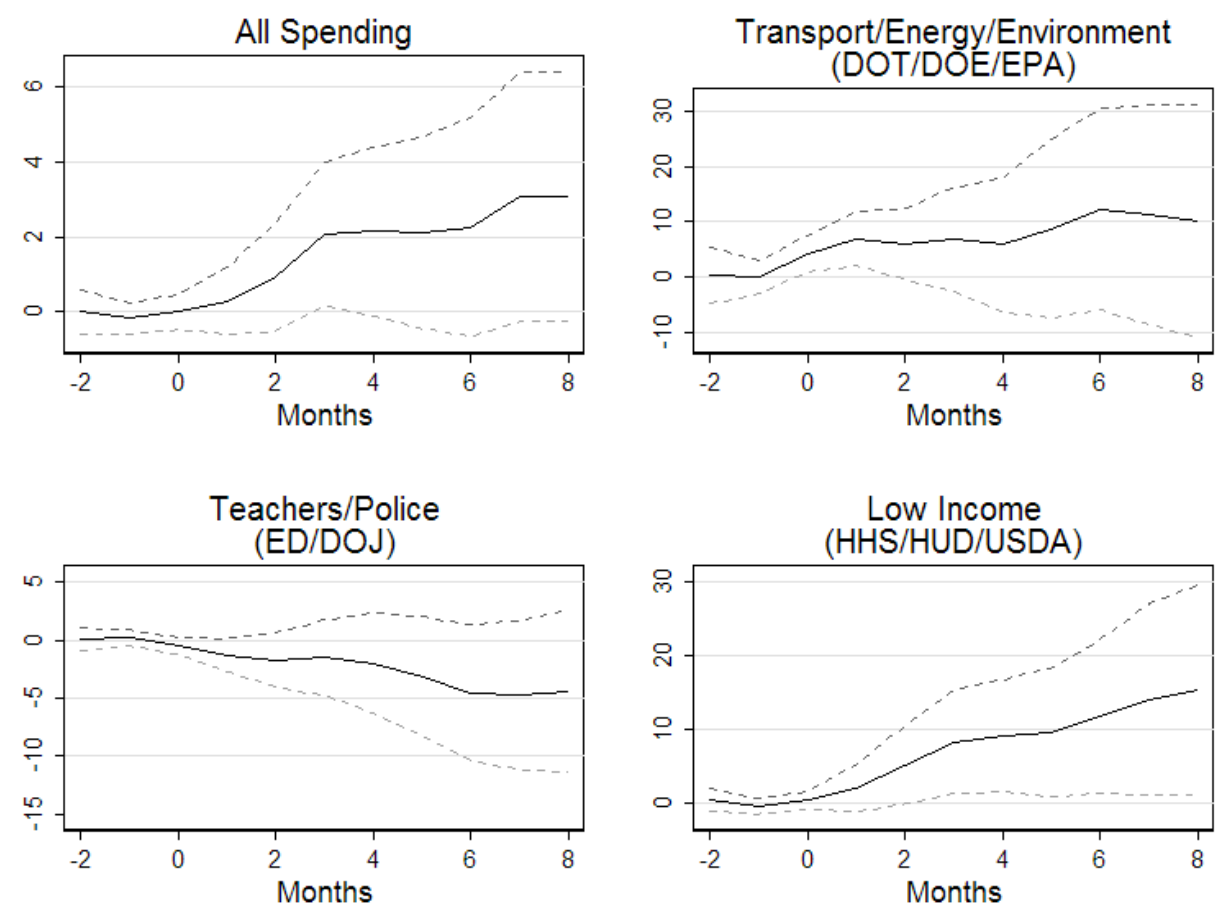

Figure 6: Support for Low Income Households
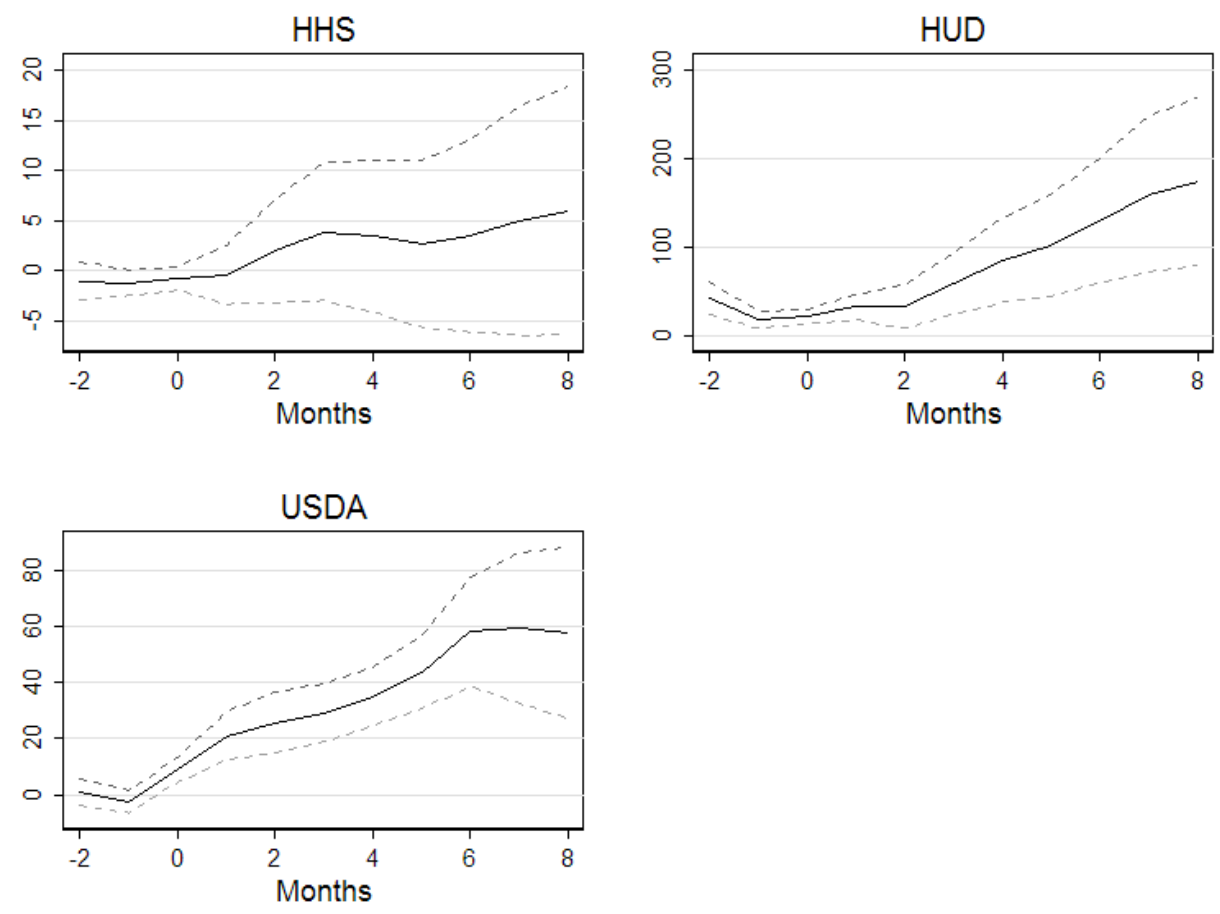
Figure 7: Teachers and Police, Building Projects
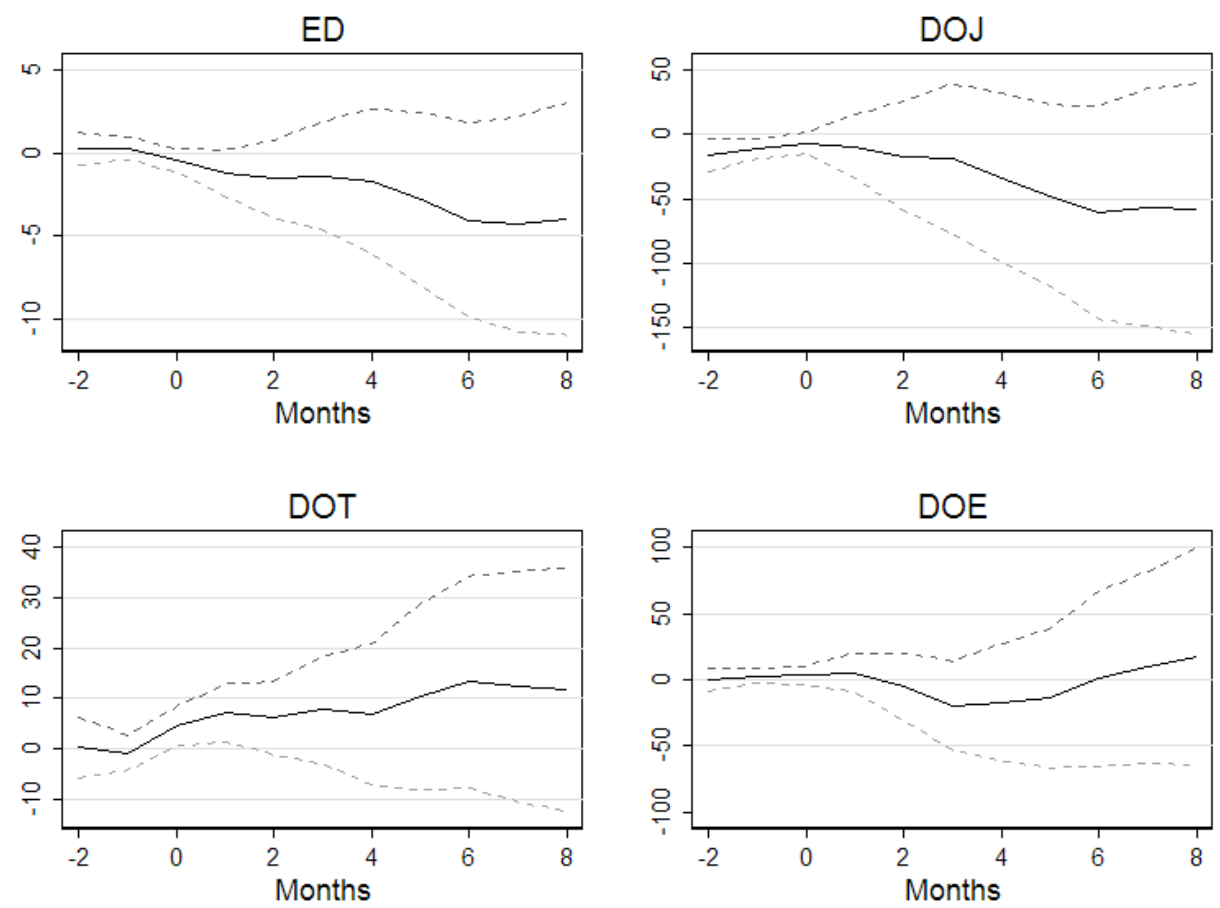

Figure 8: All Spending but Department of Education and Department of Labor

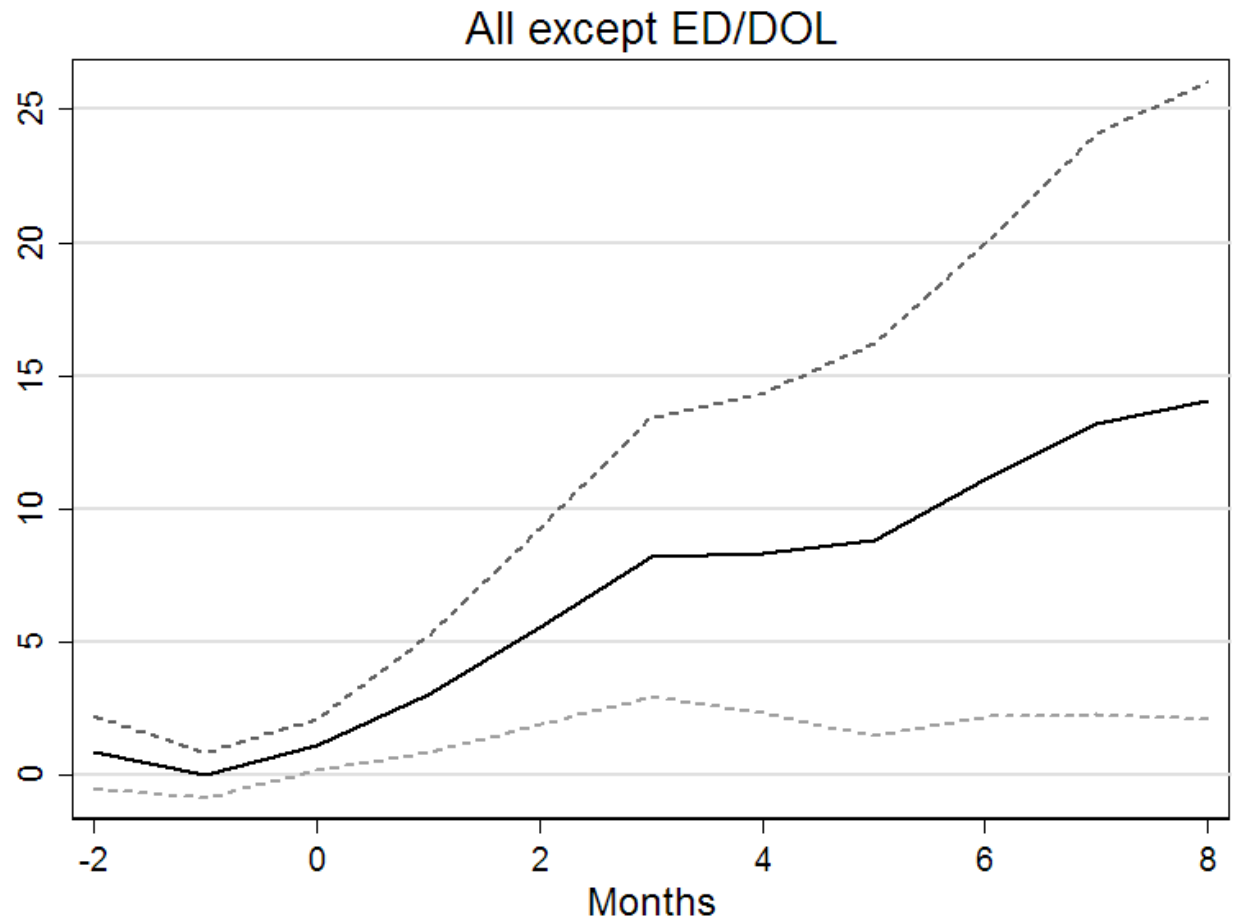


remain at this level indefinitely (which is likely a generous assumption) this indicates a cost of about $\$ 100,000$ per job over the course of a year for this subset of spending.

\section{Education Spending and Employment}

Block grants to support local education agencies have very small (and statistically insignificant) impacts on employment. At first blush this may seem surprising given that the money was described as support to avoid layoffs of needed public employees. But Figure 9 may help convince readers that ARRA's effects on education hiring were in fact small relative to the total dollars spent. We graph total employment in education month by month from 2007 through January 2011. These data are from the Current Employment Survey data used in the paper. We include state and local government employees working in education.

\section{Figure 9: Education Employment ('000) Over Time}

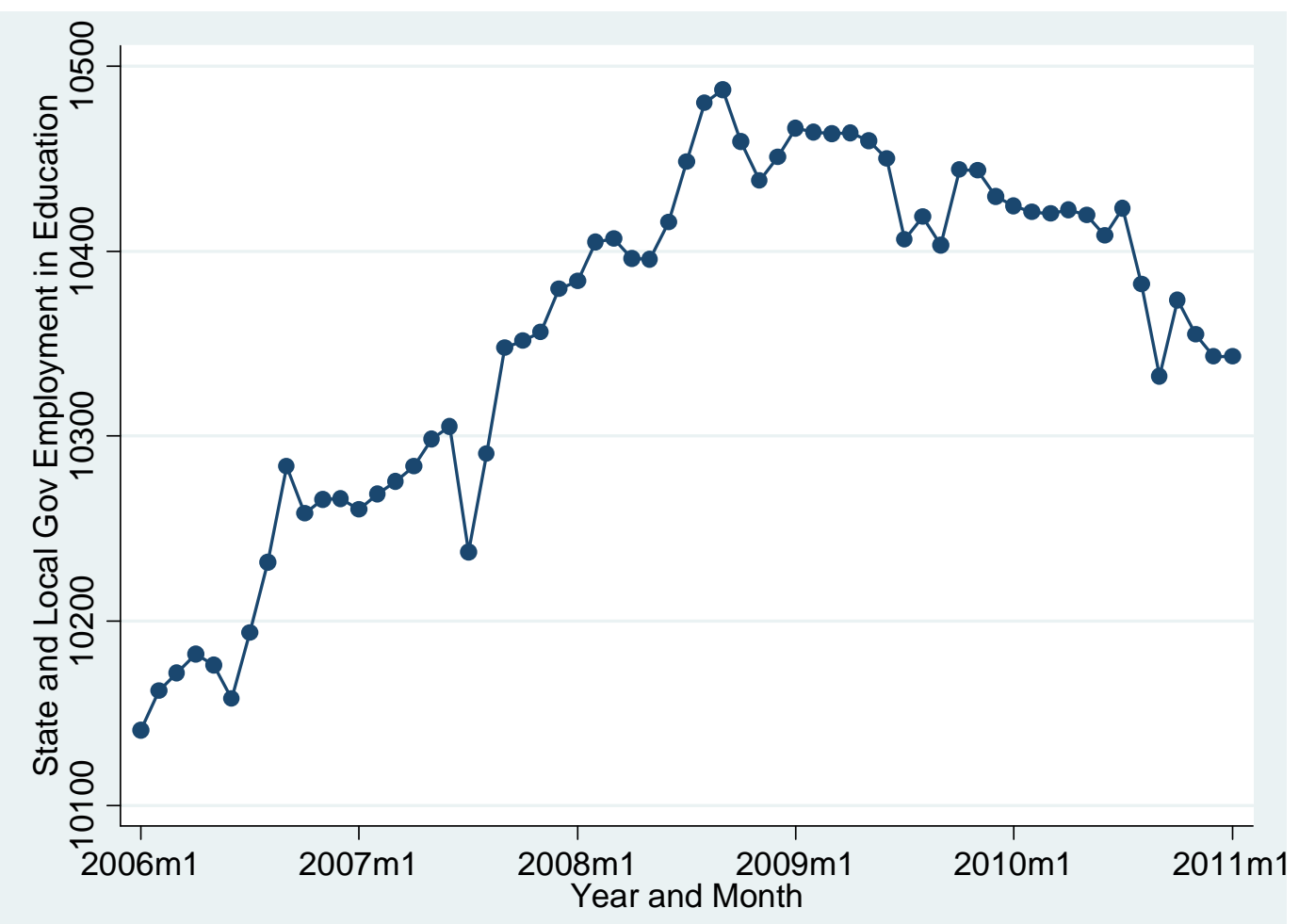

Data are from the BLS monthly Survey of Employment.

Graph shows the total number of people in the US with state and local government employment in the education sector.

Note that during the initial phase of the recession, educational employment halted its traditional growth path and dipped by about 30,000 jobs to about 10,438,000 people. Following the passage of the stimulus package, education employment had a small increase and then a slow a slow decline to about 10,400,00 jobs by June 2010. There is a sharp drop in employment 
(80,000 jobs) after June 2010. This timing may anticipate the fall in ARRA outlays that happens toward the end of 2010.

What is a plausible counterfactual for the decline of education employment in the absence of the stimulus? Perhaps in the absence of ARRA an additional 80,000 jobs would have been lost during 2009 and 2010. This would attribute all of the job loss in June 2010-2011 to the anticipated winding down of ARRA spending. If we divide the $\$ 68$ billion spent on education block grants by 80,000 jobs held for 18 months, this implies a cost of $\$ 567,000$ per job year. While that number sounds large, the raw data show that changes in educational employment were small relative to spending by the Department of Education. One needs to construct a counterfactual where education employment falls very steeply in order to generate a per job cost that is in a reasonable range.

This suggests that local government hiring patterns were at most modestly affected by these block grants. Our interviews and research indicate that State Departments of Education advised local education agencies to avoid making permanent hires since the money was explicitly temporary. Our results may imply that the block grants allowed schools to maintain their staffing patterns without increasing taxes or having states incur additional debt in order to support the schools in their state. In other words block grants for education may have funded staffing that would have occurred anyway but would have been financed through increased taxation and state and municipal debt as opposed to Federal debt. This echoes the conclusions of a recent paper by Cogan and Taylor (2010) which finds that state spending was largely unaffected by stimulus spending. If the money were spend on avoiding tax increases this may have had a stimulus effect. Cogan and Taylor suggest that much of the transfers to states were used to reduce borrowing which is likely to have limited stimulus effects. Our results are consistent with this hypothesis. 


\section{Keynesian Multipliers}

How do our results compare to traditional Keynesian multipliers? Our results are in terms of jobs created for each dollar spent. By using Okun's law we can transform job creation into GDP growth. The coefficients in the cross sectional regressions are in terms of $\beta$ jobs created by spending $\$ 100,000$. Diving by 100 ,

$$
\$ 1,000 \text { per year }=>\frac{\beta}{100} \text { jobs }
$$

If we spend $\$ 1,000$ per capita per year we get a number of jobs that is proportional to population. This allows us to express the job increase in terms of a percentage point change in the employment to population ratio (epop).

$$
\begin{gathered}
\$ 1,000 \text { per capita }=>\beta * \frac{j o b s}{p o p} * 100 \\
\$ 1,000 \text { per capita }=>\beta \% \text { increase in epop }
\end{gathered}
$$

Since the population is twice as large as the labor force (310 million/154 million), a one percent move in epop translates into a two percent move in the employment rate and a negative two percent move in the unemployment rate.

$$
\$ 1,000 \text { per capita }=>2 * \beta \% \text { decrease in } U R
$$

According to Okun's law, a one percent fall in unemployment is associated with two percent higher gdp over the course of a year.

$$
\$ 1,000 \text { per capita }=>4 * \beta \% \text { increase in GDP }
$$

GDP per capita is about $\$ 45,000$, so $\$ 1000$ per capita spending should generate a $4^{*} \beta$ percent increase in GDP per capita.

$$
\$ 1,000 \text { per capita }=>\beta * \$ 1800 \text { increase in GDP per capita }
$$

To translate our jobs per $\$ 100,000$ in monthly spending into a Keynesian spending multiplier, you therefore multiply the coefficient $\beta$ by 1.8. The coefficients in the time series regressions are in terms of jobs created by spending $\$ 100,000$ per month, so the coefficients from these regressions need to be divided by 12. The implied Keynesian multiplier is therefore the coefficient $\beta$ multiplied by 0.15 . Table 11 summarizes the implied multipliers.

Our point estimates for the stimulus as a whole suggest multipliers that are lower than the 1.6 used in the Romer-Bernstein estimates, though standard errors are large enough that we cannot reject the higher figure. Also, by performing the analysis at the state level we rule out national effects which suggest that we are understating the impact. We are more confident that the stimulus had at least some positive effect, so perfect crowding out did not occur. Excluding the transfers to the states for education, we find multiplier estimates that are larger than the Romer- 
Bernstein assumptions. This holds for both the Infrastructure and low income support categories.

Table 11: Implied Keynesian Multipliers

Cross Sectional Regressions

\begin{tabular}{l|rr}
\hline Category of Spending & J obs per \$100,000 & Implied Multiplier \\
\hline All & 0.59 & 1.06 \\
Low Income Support & 1.09 & 1.96 \\
Teachers/Police & -1.84 & -3.31 \\
DOT/DOE/EPA & 1.03 & 1.85 \\
\hline
\end{tabular}

Time Series Regressions

\begin{tabular}{l|rr}
\hline Category of Spending & $\begin{array}{l}\text { J obs per \$100,000 } \\
\text { per month (peak) }\end{array}$ & Implied Multiplier \\
\hline All & 3.1 & 0.47 \\
Low Income Support & 15.4 & 2.31 \\
Teachers/Police & -4.7 & -0.71 \\
DOT/DOE & 12.3 & 1.85 \\
All but Education & 14.1 & 2.12 \\
\hline
\end{tabular}

\section{Discussion and Conclusion}

We have presented one of the first detailed analyses of employment and earnings effects from the stimulus package that uses actual employment outcomes. ${ }^{13}$ This is important because the debate about the efficacy of fiscal policy has remained mired in the same arguments that were being made in January 2010. We hope that our analysis helps to move the discussion forward. This is important because the ARRA represents the largest exercise of countercyclical fiscal policy in the post war period. Analyses of the efficacy of the ARRA are likely to set the baseline for discretionary fiscal policy going forward.

Our results are somewhat mixed, but generally support the effectiveness of the ARRA. Our point estimates for the stimulus as a whole suggest that it was somewhat less effective than anticipated by the administration, but that their estimates are well within our confidence intervals. Overall we find a cost per job between $\$ 100,000$ and $\$ 400,000$ depending on our specification. This implies overall Keynesian multipliers between 0.5 and 2.o. By performing a state level analysis, we are excluding impacts that cross state lines, which is likely biasing our estimates of the effectiveness down.

\footnotetext{
${ }^{13}$ As far as we know, Wilson (2010) was the first paper to attempt a real time analysis of the stimulus. Our cross sectional results are broadly consistent with his.
} 
Perhaps most intriguing is our analysis of how the impacts on employment appear to differ by type of spending. Transfers to the states to support education and law enforcement appear to have little effect. This is consistent with a model where the states consider the grants to be temporary and therefore avoid making permanent changes based on the transfer. States may have used the money to lower borrowing or limit tax increases. Cogan and Taylor (2010) find that this is the case.

On the other hand, support for low income households appear to have been extremely effective with Keynesian multipliers of over 2 and a cost per job of under $\$ 100,000$. This is consistent with low income individuals having a high marginal propensity to consume. Infrastructure spending such as highway projects had impacts that were nearly a large. This all suggests that a stimulus package that did not include state level grants for local services would have been more effective per dollar than the actual stimulus package.

All of these conclusions are necessarily preliminary and incomplete. The empirical fiscal policy literature suggests that the effects of fiscal policy shocks can persist for years. Our results necessarily are limited to 2-3 quarters of data after the shocks. It will be some time before we can put together a full picture of the impacts of the ARRA but we think this preliminary analysis is valuable. We hope that this paper will help to set the stage for further analysis and move the ongoing debate in a new direction that is more directly informed by the data. 


\section{References}

BLS Handbook of Methods, Chapter 2, "Employment, hours and earnings from the establishment survey", Bulletin 2285, 1988.

Aurbach, Alan, and Yuriy Gorodnichenko, "Measuring the output Responses to Fiscal Policy," NBER working paper 16311, August 2010

Barro, Robert J. and Charles J. Redlick, "Macroeconomic Effects from Government Purchases and Taxes," September 2009. NBER Working Paper 15369.

Blanchard, Olivier and Roberto Perotti, "An Empirical Characterization of the Dynamic Effects of Changes in Government Spending and Taxes on Output," Quarterly Journal of Economics, 117(4), 2002, 1329-1368.

Cogan, John F. and John B. Taylor, "What the Government Purchases Multiplier Actually Multiplied in the 2009 Stimulus Package", working paper.

Cogan, John F., Tobias Cwik, John B. Taylor, and Volker Wieland, "New Keynesian versus Old Keynesian Government Spending Multipliers," February 2009

Clemens, Jeffrey and Stephen Miran, "The effects of state budget cuts on employment and income," NBER working paper, 2010

Feyrer, James and Jay Shambaugh, "Global Savings and Global Investment: The Transmission of Identified Fiscal Shocks,” NBER working paper 15113, 2009.

Knight, Brian, "Endogenous Federal Grants and Crowd-out of State Government Spending: Theory and Evidence from the Federal Highway Aid Program," The American Economic Review, Vol. 92, No. 1 (Mar., 2002), 71-92.

Ramey, Valerie A., and Matthew D. Shapiro. 1998. "Costly Capital Reallocation and the Effects of Government Spending," Carnegie-Rochester Conference Series on Public Policy 48, June 1998, 145-194.

Ramey, Valerie A, "Identifying Government Spending Shocks: Its All in the Timing," September 2008. Department of Econoomics, UC San Diego.

Romer, Christina. and David Romer, "The Macroeconomic Effects of Tax Changes: Estimates Based on a New Measure of Fiscal Shocks," American Economic Review, June 2010

Romer, Christina and Jared Bernstein, "The Job Impact of the American Recovery and Reinvestment Plan," January 2009.

Shoag, Daniel, "The Impact of Government Spending Shocks: Evidence on the Multiplier from State Pension Plan Returns", working paper, December 2010. 
Wilson, Daniel J, "Fiscal Spending Jobs Multipliers: Evidence from the 2009 American Recovery and Reinvestment Act,” FRBSF Working Paper 2010-17. October 2010.

Woodford, Michael, "Simple Analytics of the Government Expenditure Multiplier." American Economic Journal: Macroeconomics, 3(1): 1-35, 2011 
Table 1: Aggregate ARRA Spending By Agency and By Function

\begin{tabular}{|c|c|}
\hline & $\begin{array}{r}\text { Outlays as of } \\
9 / 2010 \\
\text { (millions) }\end{array}$ \\
\hline Health and Human Services & $\mathbf{8 4 , 2 7 5}$ \\
\hline Grants to States for Medicaid & 72,221 \\
\hline Emergency Fund for State Temporary Assistance for Needy Families & 2,679 \\
\hline Children and Families Services Programs & 1,588 \\
\hline Payments to States for Child Support Enforcement and Family Support & 1,413 \\
\hline Payments to States for the Child Care and Development Block Grant & 1,340 \\
\hline Department of Education & 62,194 \\
\hline State Fiscal Stabilization Fund & 35,352 \\
\hline Student Financial Assistance & 15,345 \\
\hline Special Education & 6,102 \\
\hline Compensatory Education for the Disadvantaged & 4,823 \\
\hline Department of Labor & 61,928 \\
\hline Payments to the Unemployment Trust Fund - Recovery Act & 36,628 \\
\hline Federal Addtl Unemployment Compensation Program & 13,928 \\
\hline Unemployment Trust Fund & 8,344 \\
\hline Training and Employment Services & 2,256 \\
\hline Department of Transportation & 20,344 \\
\hline Highway Infrastructure Investment & 14,224 \\
\hline Transit Capital Assistance & 3,100 \\
\hline Department of Agriculture & 17,592 \\
\hline Food Stamp Program & 15,616 \\
\hline Housing and Urban Development & 6,377 \\
\hline Public Housing Capital Fund - Recovery Act & 1,996 \\
\hline Project-Based Rental Assistance & 1,967 \\
\hline Home Investment Partnership Program - Recovery Act & 1,027 \\
\hline Department of Energy & 4,342 \\
\hline Energy Efficiency and Renewable Energy - Recovery Act & 3,685 \\
\hline Environmental Protection Agency & 3,720 \\
\hline State and Tribal Assistance Grants & 3,634 \\
\hline Department of J ustice & 2,084 \\
\hline State and Local Law Enforcement Assistance & 1,875 \\
\hline National Science Foundation & 597 \\
\hline Department of Homeland Security & 146 \\
\hline
\end{tabular}


Table 2

\section{Summary Statistics at the State Level}

Employment data are from the Bureau of Labor Statistics Current Employment Statistics data. (http://www.bls.gov/sae/\#tables). State level stimulus spending data are from recovery.gov agency level reports. (http://www.recovery.gov/FAQ/Pages/DownloadCenter.aspx). Seniority of congressional delegation is average seniority rank from 1 to 435 with 1 being the most senior.

\begin{tabular}{lrrrrr}
\hline \hline VARIABLE & OBS & MEAN & \multicolumn{1}{c}{ STD. } & MIN & MAX \\
& & & DEV. & & \\
Change Emp to Pop 2/o9 to 10/10 & 50 & -0.0090 & 0.0069 & -0.0395 & 0.0103 \\
Change Log Ave Earnings 2/o9 to 10/11 & 50 & -0.0188 & 0.0131 & -0.0690 & 0.0179 \\
Change Log Emp 2/o9 to 10/12 & 50 & 0.0375 & 0.0540 & -0.1127 & 0.1622 \\
Stimulus Capita in \$0o,ooo & 50 & 0.0112 & 0.0034 & 0.0075 & 0.0282 \\
Dept Transportation Stimulus Capita in \$00,000 & 50 & 0.0016 & 0.0008 & 0.0009 & 0.0048 \\
Dept Educ Stimulus Capita in \$oo,ooo & 50 & 0.0032 & 0.0004 & 0.0026 & 0.0051 \\
HHS Stimulus Capita in \$oo,ooo & 50 & 0.0020 & 0.0009 & 0.0011 & 0.0069 \\
Dept Energy Stimulus Capita in \$0o,ooo & 50 & 0.0009 & 0.0010 & 0.0003 & 0.0044 \\
Mean Seniority Rank of Congressional Delegation & 50 & 174.1191 & 50.6248 & 50.6667 & 280.2222 \\
Log Population in 2000 & 50 & 15.0599 & 1.0200 & 13.1099 & 17.3381 \\
\hline \hline
\end{tabular}

\begin{tabular}{llllll}
\hline County Level & Obs & Mean & $\begin{array}{l}\text { Std. } \\
\text { Dev. }\end{array}$ & Min & Max \\
& & & & & \\
Stimulus Per Capita in \$ooo & 3128 & 0.304 & 0.749 & 0.000 & 17.220 \\
County Population & 3128 & 89937 & 293022 & 67 & 9519338 \\
Jobs Created or Saved & 3128 & 0.002 & 0.005 & 0.000 & 0.107 \\
\hline \hline
\end{tabular}


Table 3

State Level Regressions of Employment Changes on Stimulus

Cols (1)-(2) are the long difference in employment to population ratio (employment per capita) regressed on stimulus per capita. Stimulus per capita is expressed in hundreds of thousands of dollars per person. Column (3) instruments for stimulus per capita with the seniority (average rank) of the states' congressional (US House) delegations. Cols 5-6 are state*month level Jan 2007-Oct 2010 with state and month fixed effects.

\begin{tabular}{|c|c|c|c|c|c|c|}
\hline & (1) & (2) & (3) & (4) & (5) & (6) \\
\hline & Change in & Change in & Change in & Stimulus Per & Emp/Pop & Emp/Pop \\
\hline & Emp/Pop & Emp/Рop & Emp/Рop & Capita in & (Monthly & (Monthly \\
\hline & Feb 09 to & Feb o9 to & Feb o9 to & \$'oo,00o & Panel) & Panel) (IV) \\
\hline & Oct 10 & Oct 10 & $\begin{array}{r}\text { Oct } 10 \\
\text { (IV) }\end{array}$ & (First Stage) & & \\
\hline Stimulus Per & 0.541 & 0.591 & 1.064 & & 1.383 & 2.325 \\
\hline Cap \$'oo,ooo & $(0.283)+$ & $(0.364)$ & $(0.594)+$ & & $(0.368)^{* *}$ & $(1.102)^{*}$ \\
\hline $\ln ($ pop) & & $\begin{array}{r}0.0003 \\
(0.0012)\end{array}$ & & & & \\
\hline Mean Seniority & & & & -0.000033 & & \\
\hline House Reps & & & & $(0.000008)^{*}$ & & \\
\hline Constant & -0.015 & -0.020 & -0.021 & 0.017 & 0.462 & 0.453 \\
\hline & $(0.003)^{*}$ & $(0.021)$ & $(0.007)$ & $(0.002)^{n}$ & $(0.004)^{n}$ & $(0.021)^{n}$ \\
\hline R-squared & 50 & $\begin{array}{r}50 \\
0.97\end{array}$ & 50 & 50 & 2300 & $\begin{array}{r}2300 \\
0078\end{array}$ \\
\hline & 0.071 & 0.072 & 0.005 & 0.243 & 0.979 & 0.978 \\
\hline
\end{tabular}

Standard errors in parentheses

+ significant at $10 \% ;{ }^{*}$ significant at $5 \%$; * significant at $1 \%$

\section{Table 4}

\section{State Level Regressions of Employment on Stimulus By Sector of Employment}

Regressions are as in Table II column (1) but employment is divided into all government employment, federal government, state government, local government and private sector. All columns are OLS and use state level long differences from Feb 2009 to Oct 2010.

\begin{tabular}{|c|c|c|c|c|c|}
\hline & (1) & (2) & (3) & (4) & (5) \\
\hline & Change Gov & Change Fedl & Change State & Change Local & Change Private \\
\hline & Emp/Pop & Gov Emp/Pop & Gov Emp/Pop & Gov Emp/Pop & Emp/Pop \\
\hline Stimulus Per & 0.206 & 0.007 & 0.059 & 0.136 & 0.900 \\
\hline $\begin{array}{l}\text { Capita } \\
\text { in } \$ \text { 'oo,ooo }\end{array}$ & $(0.069)^{* *}$ & (0.021) & $(0.031)+$ & $(0.055)^{*}$ & $(0.326)^{* *}$ \\
\hline Constant & $\begin{array}{r}-0.002 \\
(0.001)^{* *}\end{array}$ & $\begin{array}{r}0.000 \\
(0.000)\end{array}$ & $\begin{array}{r}-0.001 \\
(0.000)+\end{array}$ & $\begin{array}{r}-0.002 \\
(0.001)^{* * *}\end{array}$ & $\begin{array}{r}-0.008 \\
(0.004)^{*}\end{array}$ \\
\hline Observations & 50 & 40 & 48 & 50 & 50 \\
\hline R-squared & 0.158 & 0.003 & 0.073 & 0.113 & 0.137 \\
\hline
\end{tabular}

Standard errors in parentheses

+ significant at $10 \%$; ${ }^{*}$ significant at $5 \% ;{ }^{* *}$ significant at $1 \%$ 
Table 5

\section{State Level Regressions of Employment By Type of Stimulus Spending}

State Level Long Diff in Employment Per Capita Regressed on various categories of stimulus spending per capita. Based on the project level data, we created three categories of stimulus spending. Dept of Transportation and Dept of Energy projects are largely about construction and infrastructure. Dept of Education, Justice, and Dept of Homeland security provided block grants intended to enable retention of state and local government employees while Health and Human Services, HUD, and the Dept of Agriculture spending was largely on support for low income families.

\begin{tabular}{lrrr}
\hline \hline & $\begin{array}{r}(1) \\
\text { Change in Emp/Pop } \\
\text { Feb o9 to Oct 10 }\end{array}$ & $\begin{array}{r}(2) \\
\text { Change in Emp/Pop } \\
\text { Feb o9 to Oct 10 }\end{array}$ & $\begin{array}{r}(3) \\
\text { Change in Emp/Pop } \\
\text { Feb o9 to Oct 10 }\end{array}$ \\
$\begin{array}{l}\text { DOT_DOE_EPA_capita } \\
\text { (Infrastructure Spending) }\end{array}$ & 1.030 & & \\
& $(0.679)$ & & \\
ED_DOJ_capita & & -1.836 & $(2.477)$ \\
(Municipal Transfers) & & & 1.088 \\
& & & $(0.728)$ \\
HHS_HUD_USDA_capita & & -0.012 \\
(Low Income Support) & -0.012 & -0.003 & $(0.002)^{* * *}$ \\
Constant & $(0.002)^{* *}$ & $(0.008)$ & 50 \\
Observations & 50 & 50 & 0.044 \\
R-squared & 0.046 & 0.011 & \\
\hline \hline
\end{tabular}

Standard errors in parentheses

+ significant at 10\%; * significant at 5\%; ${ }^{* *}$ significant at $1 \%$

Table 6

County Level Regressions of Employment By Type of Stimulus Spending

Data on stimulus spending aggregates recipient reported data. Spending is aggregated to the county level using the recipient's zip code. We drop the counties that contain the state capitals and we drop amounts that are not categorized as locally spent, ie block grants which are passed through to the ultimate recipient. Employment data are from the Bureau of Labor Statistics Quarterly Employment Census.

\begin{tabular}{|c|c|c|c|c|}
\hline & $\begin{array}{r}\text { (1) } \\
\text { Change in } \\
\text { Emp/Pop 2009Q1 } \\
\text { to 2010Q1 }\end{array}$ & $\begin{array}{r}\text { (2) } \\
\text { Change in } \\
\text { Emp/Pop } \\
\text { (Pop Weighted) }\end{array}$ & $\begin{array}{r}(3) \\
\text { Change in } \\
\text { Emp/Pop IV }\end{array}$ & $\begin{array}{r}(4) \\
\text { First Stage }\end{array}$ \\
\hline $\begin{array}{l}\text { Stimulus Spending } \\
\text { Per Cap } \$ 00,000\end{array}$ & $\begin{array}{r}0.152 \\
(0.040)^{* *}\end{array}$ & $\begin{array}{r}0.049 \\
(0.037)\end{array}$ & $\begin{array}{r}3 \cdot 341 \\
(1.180)^{* *}\end{array}$ & \\
\hline $\begin{array}{l}\text { Mean Seniority } \\
\text { House Reps }\end{array}$ & & & & $\begin{array}{r}-7.03 \mathrm{e}-06 \\
(2.02 \mathrm{e}-06)^{* *}\end{array}$ \\
\hline Constant & $\begin{array}{r}-0.009 \\
(0.000)^{* * *}\end{array}$ & $\begin{array}{r}-0.012 \\
(0.000)^{* * *}\end{array}$ & $\begin{array}{r}-0.022 \\
(0.003)^{* * *}\end{array}$ & $\begin{array}{r}0.004 \\
(0.000)^{* *}\end{array}$ \\
\hline $\begin{array}{l}\text { Observations } \\
\text { R-squared }\end{array}$ & $\begin{array}{r}3078 \\
0.005 \\
\end{array}$ & $\begin{array}{r}3078 \\
0.001 \\
\end{array}$ & 3076 & $\begin{array}{r}3076 \\
0.004 \\
\end{array}$ \\
\hline
\end{tabular}

Standard errors in parentheses

${ }^{*}$ significant at $5 \% ;{ }^{* *}$ significant at $1 \%$ 
Table 7

\section{County Level Change In Log Wages}

We regress the change in log average wage Feb 2009 to Oct 2010 on per capita stimulus spending. Wage data are from the Quarterly Employment Census. Stimulus spending is in hundreds of thousands of dollars per capita.

\section{(1)} Change in Log Wage

Stimulus Spending Per

Capita 'oo,000

Constant

Observations

R-squared

Standard errors in parentheses

${ }^{*}$ significant at $5 \%$; ${ }^{* *}$ significant at $1 \%$
(2)

Change in Log Wage IV

10.263

$(4.767)^{*}$

$-0.007$

(0.014)

3076

\section{Table 8}

\section{County Level J obs Reported Created or Saved Regressed on Stimulus Spending}

We regress per capita reported jobs created or saved on per capita stimulus spending. Jobs created data are aggregated from recipient level reports. We exclude state capitals and money not categorized as locally spent.

(1) Reported Jobs Saved Per Capita (Equal Weighted)
(2)

Reported Jobs Saved Per Capita Pop Weighted

\section{Stimulus Spending Per}

Capita 'oo,000

$$
\begin{array}{r}
0.361 \\
(0.011)^{* *} \\
\\
0.001 \\
(0.000)^{* *} \\
3078 \\
0.248
\end{array}
$$

$$
0.000
$$$$
(0.000)^{* *}
$$

0.381

R-squared

Standard errors in parentheses

${ }^{*}$ significant at 5\%; ${ }^{* *}$ significant at $1 \%$ 
Table 9

Monthly Change In Employment Per Capita on Monthly Change in Stimulus Per Capita

Monthly Panel with Outlays and 6-8 Lags. Dependent variable is change in employment per capita.

Right hand side variables are leads and lags of changes in stimulus outlays per capita. Stimulus outlays are reported monthly by agency for each state.

\begin{tabular}{|c|c|c|c|c|c|c|}
\hline VARIABLES & $\begin{array}{r}\text { (1) } \\
\text { All Outlays } \\
\text { with } 6 \text { Lags }\end{array}$ & $\begin{array}{r}\text { (2) } \\
\text { All Outlays } \\
\text { with 8 Lags }\end{array}$ & $\begin{array}{r}(3) \\
\text { All Outlays } \\
\text { Drop Alaska }\end{array}$ & $\begin{array}{r}\text { (4) } \\
\text { All Outlays }\end{array}$ & $\begin{array}{r}(5) \\
\text { Drop Outlays } \\
\text { From Dept } \\
\text { Labor }\end{array}$ & $\begin{array}{r}(6) \\
\text { Outlays From } \\
\text { DOT DOE }\end{array}$ \\
\hline Lagged epop & & & & $\begin{array}{r}0.0724 \\
(0.07)\end{array}$ & & \\
\hline Two Month Lead & $\begin{array}{r}0.177 \\
(0.27)\end{array}$ & $\begin{array}{c}0.179 \\
(0.26)\end{array}$ & $\begin{array}{r}-0.00130 \\
(0.26)\end{array}$ & $\begin{array}{r}0.186 \\
(0.27)\end{array}$ & $\begin{array}{l}0.429 \\
(0.31)\end{array}$ & $\begin{array}{r}1.073 \\
(1.60)\end{array}$ \\
\hline One month lead & $\begin{array}{r}-0.230 \\
(0.33)\end{array}$ & $\begin{array}{l}-0.192 \\
(0.32)\end{array}$ & $\begin{array}{r}-0.0718 \\
(0.32)\end{array}$ & $\begin{array}{l}-0.193 \\
(0.32)\end{array}$ & $\begin{array}{l}0.160 \\
(0.39)\end{array}$ & $\begin{array}{r}-0.698 \\
(2.10)\end{array}$ \\
\hline Stimulus per cap & $\begin{array}{l}-0.122 \\
(0.36)\end{array}$ & $\begin{array}{r}-0.00905 \\
(0.37)\end{array}$ & $\begin{array}{r}-0.0214 \\
(0.41)\end{array}$ & $\begin{array}{r}0.00841 \\
(0.36)\end{array}$ & $\begin{array}{r}0.263 \\
(0.48)\end{array}$ & $\begin{array}{r}4.972+ \\
(2.59)\end{array}$ \\
\hline One month lag & $\begin{array}{r}0.122 \\
(0.38)\end{array}$ & $\begin{array}{r}0.295 \\
(0.42)\end{array}$ & $\begin{array}{r}0.0769 \\
(0.39)\end{array}$ & $\begin{array}{r}0.296 \\
(0.40)\end{array}$ & $\begin{array}{c}0.354 \\
(0.63)\end{array}$ & $\begin{array}{r}4.226^{*} \\
(1.70)\end{array}$ \\
\hline Two month lag & $\begin{array}{r}0.387 \\
(0.46)\end{array}$ & $\begin{array}{l}0.636 \\
(0.50)\end{array}$ & $\begin{array}{l}0.400 \\
(0.50)\end{array}$ & $\begin{array}{r}0.619 \\
(0.47)\end{array}$ & $\begin{array}{r}0.867 \\
(0.68)\end{array}$ & $\begin{array}{r}-0.701 \\
(2.41)\end{array}$ \\
\hline Three month lag & $\begin{array}{l}0.825^{*} \\
(0.40)\end{array}$ & $\begin{array}{r}1.151^{* *} \\
(0.42)\end{array}$ & $\begin{array}{l}0.929^{*} \\
(0.39)\end{array}$ & $\begin{array}{r}1.104^{* *} \\
(0.40)\end{array}$ & $\begin{array}{r}1.268+ \\
(0.65)\end{array}$ & $\begin{array}{r}1.503 \\
(2.58)\end{array}$ \\
\hline Four month lag & $\begin{array}{r}-0.365 \\
(0.58)\end{array}$ & $\begin{array}{r}0.0686 \\
(0.51)\end{array}$ & $\begin{array}{l}0.270 \\
(0.53)\end{array}$ & $\begin{array}{r}-0.00852 \\
(0.53)\end{array}$ & $\begin{array}{r}0.188 \\
(0.55)\end{array}$ & $\begin{array}{r}0.0942 \\
(2.56)\end{array}$ \\
\hline Five month lag & $\begin{array}{r}-0.581+ \\
(0.32)\end{array}$ & $\begin{array}{r}-0.0372 \\
(0.39)\end{array}$ & $\begin{array}{r}-0.133 \\
(0.41)\end{array}$ & $\begin{array}{r}-0.0392 \\
(0.39)\end{array}$ & $\begin{array}{r}-0.233 \\
(0.53)\end{array}$ & $\begin{array}{l}3.984 \\
(3.99)\end{array}$ \\
\hline Six month lag & $\begin{array}{r}-0.500 \\
(0.38)\end{array}$ & $\begin{array}{r}0.152 \\
(0.58)\end{array}$ & $\begin{array}{l}-0.181 \\
(0.50)\end{array}$ & $\begin{array}{r}0.161 \\
(0.56)\end{array}$ & $\begin{array}{r}0.155 \\
(0.75)\end{array}$ & $\begin{array}{r}4.096^{*} \\
(1.98)\end{array}$ \\
\hline Seven month lag & & $\begin{array}{r}0.816 \\
(0.50)\end{array}$ & $\begin{array}{l}0.497 \\
(0.41)\end{array}$ & $\begin{array}{r}0.821+ \\
(0.48)\end{array}$ & $\begin{array}{l}0.608 \\
(0.67)\end{array}$ & $\begin{array}{r}-0.466 \\
(1.74)\end{array}$ \\
\hline Eight month lag & & $\begin{array}{l}0.239 \\
(0.35)\end{array}$ & $\begin{array}{r}0.115 \\
(0.36)\end{array}$ & $\begin{array}{l}0.201 \\
(0.36)\end{array}$ & $\begin{array}{l}0.409 \\
(0.41)\end{array}$ & $\begin{array}{r}-0.567 \\
(1.75)\end{array}$ \\
\hline Constant & $\begin{array}{r}0.000647^{* *} \\
(0.00)\end{array}$ & $\begin{array}{r}-0.000734^{* *} \\
(0.00)\end{array}$ & $\begin{array}{r}-0.00076^{* *} \\
(0.00)\end{array}$ & $\begin{array}{r}-0.000683^{* *} \\
(0.00)\end{array}$ & $\begin{array}{r}-0.000741^{* *} \\
(0.00)\end{array}$ & $\begin{array}{r}-0.000741^{* * *} \\
(0.00)\end{array}$ \\
\hline Observations & 1850 & 1750 & 1715 & 1750 & 1750 & 1750 \\
\hline R-squared & 0.47 & 0.47 & 0.50 & 0.48 & 0.47 & 0.48 \\
\hline
\end{tabular}


Table 10

Monthly Change In Employment Per Capita on Monthly Change in Stimulus Per Capita By Federal Agency

Monthly Panel using outlays and 8 Lags. Dependent variable is change in employment per capita. Right hand side variables are leads and lags of changes in stimulus outlays per capita. Stimulus outlays are reported monthly by agency for each state. Each column uses outlays from a different federal agency.

(1) VARIABLES Outlays From DOT
(2)

Outlays From DOE
One month lead

One month lead

Change stimulus capita

One month lag

Two month lag

Three month lag

Four month lag

Five month lag

Six month lag

Seven month lag

Eight month lag

Constant

Observations

R-squared

$\begin{array}{rr}1.082 & -2.933 \\ (2.03) & (4.07) \\ -0.809 & 2.879 \\ (2.72) & (3.94) \\ 4.504 & 3.082 \\ (3.06) & (5.68) \\ 2.652 & 2.349 \\ (1.60) & (6.67) \\ -1.055 & -11.09 \\ (2.69) & (10.35) \\ 1.668 & -13.92 \\ (2.96) & (9.69) \\ -0.937 & 2.356 \\ (3.12) & (10.04) \\ 3.534 & 3.220 \\ (4.64) & (11.87) \\ 2.893 & 14.63 \\ (2.10) & (20.34) \\ -0.895 & 8.542 \\ (1.93) & (7.77) \\ -0.624 & 7.820 \\ (1.90) & (12.04) \\ & \end{array}$

1.082

(2.72)

(3.06)

2.652

(1.60)

-1.055

(2.69)

(2.96)

$-0.937$

(3.12)

3.534

(4.64)

2.893

(2.10)

$-0.895$

$-0.624$

(1.90)
$-0.000707^{* *}$
$(0.00)$

$-2.933 \quad-1.010$

(0.63)

$-1.644+$

(0.89)

$-0.868$

(0.67)

0.655

(0.62)

$-0.164$

(0.61)

0.688

(0.62)

$-0.377$

(0.84)

0.338

(0.84)

$-0.156$

(0.97)

1.227

(0.81)

$-0.691$

(0.57)
3)

$\mathrm{L}$

(4)

Outlays From ED

From HHS From USDA

$\begin{array}{rrr}-0.0718 & 0.160 & 3.352^{*} \\ (0.31) & (0.63) & (1.53) \\ 0.296 & -1.213 & -2.499 \\ (0.53) & (0.99) & (3.14) \\ -0.458 & -0.823 & 8.842^{*} \\ (0.57) & (0.91) & (3.36) \\ -0.761 & 0.387 & 12.15^{*} \\ (0.64) & (1.55) & (5.06) \\ -0.331 & 2.410 & 4.643+ \\ (0.82) & (1.85) & (2.57) \\ 0.188 & 1.893 & 3.566 \\ (0.80) & (1.44) & (3.98) \\ -0.318 & -0.413 & 5.768 \\ (1.00) & (1.20) & (3.59) \\ -1.080 & -0.835 & 8.482+ \\ (0.78) & (1.03) & (4.27) \\ -1.262 & 0.824 & 14.49+ \\ (0.76) & (1.24) & (7.84) \\ -0.244 & 1.504 & 1.471 \\ (0.72) & (1.76) & (7.24) \\ 0.340 & 0.983 & -1.918 \\ (0.64) & (1.00) & (5.35)\end{array}$

$3 \cdot 35^{*}$

(1.53)

2.499

$842^{*}$

$(3.36)$

$12.15^{*}$

(5.06)

$643^{+}$

3.566

$(3.98)$

5.768

(3.59)

.482+

$4.49+$

(7.84)

1.471

$\begin{array}{ll}0.983 & -1.918 \\ (1.00) & (5.35)\end{array}$

$\begin{array}{ll}0.983 & -1.918 \\ (1.00) & (5.35)\end{array}$

\begin{tabular}{|c|c|c|c|c|c|c|}
\hline Constant & $\begin{array}{r}-0.000707^{* *} \\
(0.00)\end{array}$ & $\begin{array}{r}-0.000692^{* *} \\
(0.00)\end{array}$ & $\begin{array}{r}-0.000691^{* *} \\
(0.00)\end{array}$ & $\begin{array}{r}-0.000677^{* *} \\
(0.00)\end{array}$ & $\begin{array}{r}-0.000712^{* *} \\
(0.00)\end{array}$ & $\begin{array}{r}-0.000747^{* *} \\
(0.00)\end{array}$ \\
\hline Observations & 1750 & 1750 & 1750 & 1750 & 1750 & 1750 \\
\hline R-squared & 0.48 & 0.47 & 0.47 & 0.47 & 0.48 & 0.47 \\
\hline
\end{tabular}

